\title{
1: 155859720-155845348
}

National Cancer Institute

\section{Source}

National Cancer Institute. 1:155859720-155845348. NCI Thesaurus. Code C41673.

Physical location of AIM2_Gene 